IZA DP No. 4739

Demographics, Fiscal Health, and School Quality: Shedding Light on School Closure Decisions

Sherrilyn M. Billger

February 2010 


\title{
Demographics, Fiscal Health, and School Quality: Shedding Light on School Closure Decisions
}

\author{
Sherrilyn M. Billger \\ Illinois State University \\ and IZA
}

\section{Discussion Paper No. 4739 \\ February 2010}

\author{
IZA \\ P.O. Box 7240 \\ 53072 Bonn \\ Germany \\ Phone: +49-228-3894-0 \\ Fax: +49-228-3894-180 \\ E-mail: iza@iza.org
}

Any opinions expressed here are those of the author(s) and not those of IZA. Research published in this series may include views on policy, but the institute itself takes no institutional policy positions.

The Institute for the Study of Labor (IZA) in Bonn is a local and virtual international research center and a place of communication between science, politics and business. IZA is an independent nonprofit organization supported by Deutsche Post Foundation. The center is associated with the University of Bonn and offers a stimulating research environment through its international network, workshops and conferences, data service, project support, research visits and doctoral program. IZA engages in (i) original and internationally competitive research in all fields of labor economics, (ii) development of policy concepts, and (iii) dissemination of research results and concepts to the interested public.

IZA Discussion Papers often represent preliminary work and are circulated to encourage discussion. Citation of such a paper should account for its provisional character. A revised version may be available directly from the author. 
IZA Discussion Paper No. 4739

February 2010

\section{ABSTRACT}

\section{Demographics, Fiscal Health, and School Quality: Shedding Light on School Closure Decisions}

In our current challenging budgetary environment, school closures remain a potentially attractive choice. With a large panel of Illinois schools from 1991 to 2005, I investigate which factors contribute to school closures. Among elementary schools, declining enrolments and rural locations coincide with closures. However, schools with higher per-pupil spending are ceteris paribus less likely to close. Furthermore, better test scores also yield lower probabilities. High expenditures contribute to junior high closure, but the most significant predictors are the proportions of black and low income students. Administrators may claim that low enrolments and high spending motivate school closures, but in Illinois, that is not the whole story.

JEL Classification: $\quad$ I22, I28, H75

Keywords: education finance, education administration, school closures, tax policy

Corresponding author:

Sherrilyn M. Billger

Department of Economics

Illinois State University

Campus Box 4200

Normal, IL 61790-4200

USA

E-mail: smbillg@ilstu.edu

\footnotetext{
* This project is supported by the Cooperative State, Research, and Extension Service, U.S. Department of Agriculture, under award No. ILLR-2006-03018. I am grateful to Frank Beck, Norm Durflinger, and Joe Pacha for their contributions to the overall project, and I thank Jenna Bertschi, Eric Cheriyuot, Bishal Kasu, and especially Brandon Curtis for excellent research assistance.
} 


\section{Why Do Public Schools Close?}

At first pass, seeking the reason a school closes may appear moot; declining enrolments and growing expenditures are generally cited as the justification for school closures. However, it is not true that all schools with the lowest enrolments or the highest spending have been (or eventually will be) closed. The determinants of closure decisions are complex, including fiscal health, community demographics and economic conditions, and local power structures. However, there is little existing Economic literature on the causes of school closures. Pandey et al. (2009) focus on private schools, which are presumably run somewhat differently from public schools. Unsurprisingly, they find that younger and smaller schools are more likely to close. In an interesting piece from the geography literature, Basu (2004) explores the community power structures that effect school closures. He finds that "unemployed families with children, lone-parent families, renters with affordability problems, and new-immigrant groups were at a greater disadvantage in protecting their schools,” (p. 449) highlighting substantial inequity in school closure decisions.

Additional research related to this area studies school and district consolidation, which often coincides with school closures. The most common driving forces are declining population, difficulty raising revenue, and declining property values (Brasington 1999; Ratcliffe, Biddle, and Younger 1990). Community size also matters. Brasington (2003) reports that larger communities are more willing to consolidate, despite the substantial economies of size gains that smaller schools would likely experience post-consolidation. In some ways, consolidation appears to benefit schools and districts, but Gordon and 
Knight (2008) find that Iowa did not experience lower pupil-teacher ratios, stronger enrolments, or lower dropout rates after district consolidation.

Consolidations and school closures are generally motivated by desires to improve student outcomes and school efficiency by taking advantage of economies of size. Indeed, the literature highlights numerous ways that "bigger is better" in education. Among others, Duncombe and Yinger (2007) and Chakraborty et al. (2000) find scale economies as higher enrolments yield lower average costs. Duncombe et al. (1995) focus on rural schools in New York and document direct per-pupil expenditure improvements arising from enrolment increases. Dodson and Garrett (2004) quantify benefits in Arkansas amounting to $\$ 40$ million dollars. On the other hand, consolidations into larger schools can have unintended consequences. For instance, Sell et al. (1996) report lower sales, lower income, and higher unemployment in communities that lost their schools.

Attempts to effectively manage schools can be made more challenging through legal reforms, government budgeting, and local tax referenda. Gordon (2004) reveals that federal Title I funding intended to benefit schools with the poorest children has little lasting effect on schools that should receive the funds; local governments are effectively able to crowd-out Title I changes within 3 years. Murray et al. (2007) provide a rather disturbing future outlook for education funding, as more senior populations are expected to provide less and less support for schools. Furthermore, "the elderly are less likely to support increases in school spending when the children in their community are of a different race,” (p. 343), suggesting additional difficulties in diverse areas. 
One way local residents attempt to curb public spending is through tax caps. The existing literature in this area is rather grim, often finding that student performance suffers in the presence of tax limits. Dye et al. (2005) report that tax limits in Illinois did indeed curb growth in school expenditures. If this revealed efficiency gains, we would certainly be pleased. However, existing work suggests that administrative expenses are rarely cut, in favor of reducing instructional expenditures. Downes and Figlio (1999) find evidence that student performance is lower in the long run, particularly in economically disadvantaged communities. State and local governments attempt to maintain revenue through other sources, which are generally regressive in practice.

Regardless of the funding source, we do know that school and district policies affect student outcomes. Curriculum choice, staffing, and other policies translate to student performance. For example, Steifel et al. (2003) analyze the optional Performance Driven Budgeting (PDB) Initiative in New York state. The goal of PDB is to transfer administrative power from more centralized units to specific schools. The authors find that PDB encouraged little reallocation of resources, but did contribute to significantly higher student test scores. A caveat to this research is that participation was optional, suggesting there may have been some selection bias, though fixed effects mitigate that concern to some extent. Nonetheless, it is not clear whether more localized control would universally benefit students. 
Addonizio (2009) examines x-efficiency with a panel of elementary schools. While school policies are truly important, a student's socioeconomic status remains a significant indicator of test performance. On the margin, the culture within a school contributes more to its success than the specific allocation of funds, suggesting that true school quality is difficult to incentivize in our current system. With the backdrop of tight budgets, local tax limits, changing demographics, and top-down accountability, administrators face increasingly challenging environments. School closures are seen as one possible route to improved fiscal conditions and student outcomes. The decision to close a specific school may simply be argued as a budgetary necessity. On the other hand, the school culture, community support, economic conditions, and political power may also play a role. In this study I set out to provide additional insight into these choices.

\section{Comparing Schools that Close to Schools that Remain Open}

This study focuses on elementary and junior high schools throughout Illinois. Cook County schools are excluded because they are generally considered a separate entity from the rest of the state. Illinois has seen thousands of school closures since the 1940s. Some of these have been high schools, but the vast majority of closed schools were elementary schools. Figure 1 plots the number of schools closed in Illinois (excluding Cook County) from 1972 (earliest available annual data) through 2005. School closures follow a cyclical pattern, and the jump from 1973 to 1974 may simply arise from how closures were recorded at the State Board of Education. In general, there are more school closures in weak economic climates. The overall trend in closures has declined since the 1970s, 
presumably because there are fewer schools to close and open schools have become more efficient.

Figures 2 and 3 examine some key components over time. The last year a school is in operation is set to be $t=0$, and these figures plot average values beginning 10 years before a school closes. For instance, the first panel in Figure 2 shows the increasing trend in per-pupil expenditures among elementary schools that have closed between 1991 and 2005. As expected, school enrolment also declines precipitously before an elementary school closes its doors. Education fund, EAV per pupil, and median house values (all somewhat-related variables) display increasing trends, though not consistently. Finally, we see that the proportion of the local population that is school-aged is basically flat until 5 years prior to a closure, when population rises. Considered along with declining enrolments, it may be the case that families are moving into the area, or having more children, but they are not attending their public school.

Trends for junior high school closures appear in Figure 3. In general, these trends are less smooth than those plotted among elementary schools because the sample is substantially smaller (221 elementary schools closed during the period, while only 60 junior high schools closed). There appear to be some substantive differences here. Expenditures rise, and school enrolments decline, though not consistently. Education fund and EAV appear to be trending downward, while median house values are rising somewhat. Overall, school-aged population is declining in these communities, concurrent with school enrolments. Taken together, these figures suggest that rising per- 
pupil expenditures are the most important factor determining elementary and junior high school closure decisions.

The data used for the majority of this analysis covers 1991 through 2005. Data sources include the Illinois State Board of Education's annual School Report Card, the U.S. Census, the Bureau of Labor Statistics, the Illinois Department of Employment Security, and distances calculated in Google Maps. The data set contains a wealth of information on schools, districts, towns, and counties, and this study focuses on all public elementary and junior high schools in Illinois, except in Cook County. Within the time frame, 221 of 1698 elementary schools closed, and 60 of 515 junior highs.

Summary statistics appear in Tables 1 and 2. There are large differences between elementary schools that close and those that remain open. Enrolments are particularly striking, on average 239 at schools that close and 383 at schools that stay open. Closed schools had a larger proportion of black and low income students, and a slightly lower attendance rate. Across all fiscal measures, closed schools were poorer and spent less on students, while facing higher tax rates. We also see that elementary districts are significantly less likely to close their schools. When comparing quality, we see some evidence that closed schools were not performing as well in math and reading. As expected, closed elementary schools were located in poorer and more rural residential areas with relatively small school-aged populations. 
Junior high schools exhibit similar comparisons in terms of enrolment, demographics, and fiscal variables. Per-pupil expenditures are lower—as are reading and math test scores—at junior high schools that closed. Economic conditions are also worse in the towns that housed closed schools. These areas also tend to be rural with lower levels of education. One potentially surprising result in these tables is the correlation of tax caps with school closures. In counties with property tax caps, elementary and junior high schools are significantly less likely to close. The remainder of this paper will investigate these factors more carefully in order to better determine the main causes of school closures.

\section{Estimating the Likelihood of Closing a School}

The factors that contribute to the decision to close an elementary or junior high school include school and district finance, socio-demographics, and local economic conditions. Using the wide array of data in this sample, I estimate the likelihood of a school closure with the specification

(1) $\quad \operatorname{Prob}\left(\right.$ school closes $\left._{i}=1\right)=f\left(S_{i t}, D_{i t}, C_{i t}\right)$

where closes $=1$ for each elementary or junior high school that closes during the period 1991-2005. Probits are run separately for each level of school. To begin, the dependent variable is time-invariant, but this will be relaxed in further analysis. $S$ contains the school data for student enrolment, racial composition, low income students, and math and reading test scores. $D$ is the district data for per pupil expenditures, equalized assessed value, education fund tax rate, school tax rate, teacher salary, average teacher experience, and a district indicator for either elementary or unit district, depending upon the 
specification. ${ }^{1}$ Community characteristics are in $C$, and include data measured at the town or county level. Town variables are poverty rate, indicators for ERS urban/rural designations, agricultural employment, immigrant population, median house value, median household income, and owner-occupied housing vacancy rate. County data are community educational attainment, school-aged population, unemployment rate, and whether the county has a property tax cap. Some of the community characteristics are only measured decennially, and a linear trend was used to impute values for intervening years.

Equation (1) is estimated with maximum likelihood probit. Rather than coefficient estimates, I report marginal effects evaluated at the mean of each continuous variable, or for the change in probability as a binary variable goes from zero to one. For example, the marginal effect of the school tax rate is calculated as:

$$
\frac{\partial \Phi(S \hat{\beta}, D \hat{\delta}, C \hat{\gamma})}{\partial s c h o o l t a x r a t e}=\phi(\bar{S} \hat{\beta}, \bar{D} \hat{\delta}, \bar{C} \hat{\gamma}) \hat{\beta}_{\text {schooltaxrate }}
$$

Results include robust standard errors that allow for dependence within schools over time. $^{2}$

Probit marginal effects estimates for Equation (1) appear in Tables 3 through 7. Focusing initially on elementary schools, we see that enrolment is a major predictor of which schools will close. If enrolment rises by one percent, the likelihood of closure falls by ten percent. It may be surprising that expenditures are negatively related to closures, but this

${ }^{1}$ Illinois has three types of districts: elementary, high school, and unit.

2 Since the data include many more open schools than closed schools, random effects probit estimates are unstable. Fortunately, standard probit estimates that allow for error correlation within schools over time provide a suitable substitute. 
could be correlated with school quality that is not reflected in test scores. On the other hand, elementary schools with more low income students are significantly more likely to close. Controlling for other fiscal measures, tax rates are not significantly correlated with closure decisions. Turning our attention to community characteristics, the most important factor is the urbanicity of the area. Unsurprisingly, more urban schools are, ceteris paribus, less likely to close. We also see that property tax caps have no significant effect on elementary school closures. The most unexpected finding here is that the size of the school-aged population appears to be insignificant.

Given the relatively small number of closed junior high schools, it is difficult to predict the determinants of these decisions. In Table 5, the only persistent contributing factor is the proportion of black students. On the other hand, junior high schools in areas with high poverty are somewhat more likely to be closed, challenging conventional wisdom. In this specification, property tax caps do matter. Schools in counties with caps are actually less likely to close. However, before this is taken to a potentially troubling policy implication, it is important to examine the full model that incorporates all school and community data.

Marginal effect estimates for the full specifications appear in Table 7. There are stark differences between elementary and junior high schools. Higher enrolments lower the likelihood that an elementary school will close, but have no effect on junior highs. Though high expenditures and tax rates are often cited as the motivation to close schools, we see no evidence of that here. Tax rates and tax caps have no significant effect on 
whether a school closes, and higher expenditures lower the probability of an elementary school closure, but by a small magnitude. The local economic environment has some impact, where poverty contributes to closing junior high schools. Larger immigrant populations reduce school closures, for reasons that are not immediately apparent. Perhaps communities with more immigrants are growing in ways the other indicators (such as school-aged population) do not measure.

There are indeed some surprising results in Table 7. Following conventional wisdom, most urban elementary schools are significantly less likely to close, compared to their rural counterparts. The exception to this is schools in very large metro areas. On the other hand, location appears irrelevant in decisions to close junior high schools. What does matter is race. Controlling for a wide array of school and community characteristics, junior highs with more black students are significantly more likely to close. Giving the small number of significant parameters, this result is particularly interesting. Perhaps schools with many black students exist in a more vulnerable political climate within their communities. I have also examined whether test scores effect closures, since accountability is increasingly important to administrators and policymakers. Though the magnitude of the effect is not particularly large, it remains true that poor academic performance is correlated with a greater likelihood that an elementary school will close. In sum, lower-quality elementary schools, those with declining enrolments, and those in rural or very large metro areas are in greatest danger of closing. Junior high schools with fewer black students, larger immigrant populations, or higher expenditures are less likely to be closed. 
As a robustness check, I use the panel data to investigate the impact of trends in the most important variables. The specification is as follows:

(3) $\operatorname{Prob}\left(\right.$ closes $\left._{i t}=1\right)=\operatorname{Prob}\left[\left(\alpha_{1} S_{i t}+\alpha_{2} \Delta S_{i t-k}+\alpha_{3} D_{i t}+\alpha_{4} \Delta D_{i t-k}+\alpha_{5} C_{i t}+\varepsilon\right)>0\right]$

where the dependent variable equals one in the last year the school is open. The variables that are included as $t-k$ trends are $\ln ($ enrolment), EAV per pupil, education fund rate, school-aged population, and test scores. All fiscal variables were determined in the prior year's budget, so that the budget decided in year $t-1$ is reported here in the figures in effect for year $t$. I included linear trends across the previous 3, 5, and 7 years.

Selected coefficient estimates for elementary schools appear in Table 8. Specifications using 3- and 7- year trends are reported here, and separated into subgroups of interest. As expected, enrolment remains important, particularly in schools with the highest levels of per pupil expenditures. There is some evidence that rising education fund rates yield a lower likelihood of school closure. Surprisingly, 3-year growth trends in school age population correlate with higher closure probabilities. Since this result controls for enrolment, we may be seeing the effects of an exodus from public schools into private, charter, and home schools in these areas. The coefficients are rather small in magnitude, but we do see some relationship between test scores and closures, particularly in reading. Across the board, the model exhibits better fit for shorter durations. Taken together, it appears that the time horizon for elementary school closure decisions is quite short. That is, schools do not seem to languish with low enrolments, high expenditures, and low test scores. 
Table 9 lists parameter estimates for the junior high school sample. Since the sample is

relatively small, it is not illustrative to include results for subsets like those in Table 8. Nonetheless, we see some interesting results across the full sample. Revenue available to schools is most important, and higher levels of EAV significantly reduce the likelihood that a junior high will close. Trends appear less important for junior highs than for elementary schools. It is also important to note, that due to limited degrees of freedom, these specifications do not include test scores.

\section{Concluding Remarks}

School administrators and policymakers continually seek scale economies, great fiscal health, and stronger student performance. To this end, many public schools are closed, citing unsustainably low enrolments and/or skyrocketing per-pupil expenditures. At first pass, these factors appear pivotal in school closure decisions. Among elementary schools that closed in the time period 1991-2005, expenditures rose $21 \%$ on average, over the ten years prior to closure. Through the four years prior to closing a junior high, enrolment fell 35\%, on average. Unfortunately, far more factors impact these choices; no school operates in a fiscal vacuum. With increasingly robust specifications, I show the importance of additional school and community characteristics.

Unsurprisingly, elementary schools with declining enrolments are more likely to close, as are rural schools. On the other hand, higher per-pupil spending coincides with lower probabilities of closure. Perhaps this reveals something about a school's quality or the 
parents' support of their school. Indeed, academic performance seems to matter. Better test scores in reading and math help to protect a school from closure. Perhaps dollars are less a concern if the school is strong. High expenditures increase the likelihood a junior high will close. On the other hand, the prevalence of black and low income students is a more significant contributing factor. In a potentially surprising result, local tax concerns have no clear impact on school closures—-tax caps will neither sink nor save a school. In sum, the schools most likely to close are not simply the smallest or most expensive schools. Race, socioeconomic status, and student performance play a role. It behooves researchers, policymakers, and administrators to be more aware of the importance of political power and school quality in school closure decisions. 


\section{References}

Addonizio, Michael F. 2009. "X-Efficiency and Effective Schools: A New Look at Old Theories," Journal of Education Finance, 35(1): 1-25.

Basu, Ranu. 2004. "A Flyvbjergian Perspective on Public Elementary School Closures in Toronto: A Question of 'Rationality' or 'Power'? Environment and Planning C:

Government and Policy, 22: 423-451.

Brasington, David M. 1999. "Joint Provision of Public Goods: The Consolidation of School Districts.” Journal of Public Economics, 73: 373-393.

Brasington, David M. 2003. "Size and School District Consolidation: Do Opposites Attract?” Economica, 70:673-690.

Chakraborty, Kalyan, Basudeb Biswas, and W. Cris Lewis, 2000. "Economies of Scale in Public Education: An Econometric Analysis,” Contemporary Economic Policy, 18(2): 238-247.

Coates, Dennis C., and Douglas J. Lamdin. 2002. "School Performance Evaluation Using Data Envelopment Analysis," Public Finance and Management, 2(4), 566-591.

Dodson, Marvin E., III, and Thomas A. Garrett, 2004. "Inefficient Education Spending in Public School Districts: A Case for Consolidation?” Contemporary Economic Policy, 22(2): 270-280.

Downes, Thomas A., and David N. Figlio. 1999. "Do Tax and Expenditure Limits Provide a Free Lunch? Evidence on the Link Between Limits and Public Sector Service Quality,” National Tax Journal, 52(1), pp. 113-128.

Duncombe, William, and John Yinger, 2007. "Does School District Consolidation Cut Costs?” Education Finance and Policy, 2(4): 341-375.

Duncombe, William, Jerry Miner, and John Ruggiero. 1995. "Potential Cost Savings from School District Consolidation: A Case Study of New York,” Economics of Education Review, 14(3): 265-84.

Dye, Richard F., Therese J. McGuire, and Daniel P. McMillen. 2005. “Are Property Tax Limitations More Binding over Time?” National Tax Journal, 58(2), pp. 215-225.

Gordon, Nora. 2004. "Do Federal Grants Boost School Spending? Evidence from Title I,” Journal of Public Economics, 88(9-10), pp. 1771-1792.

Gordon, Nora, and Brian Knight. 2008. "The Effects of School District Consolidation on Educational Cost and Quality, Public Finance Review, 36(4), pp. 408-430. 
Murray, Sheila E., Kim Rueben, and Carol Rosenberg. 2007. "State Education Spending: Current Pressures and Future Trends,” National Tax Journal, 60(2), pp. 325-345.

Pandey, Lakshmi, David L. Sjoquist, and Mary Beth Walker. 2007. “An Analysis of Private School Closings,” Education Finance and Policy, 4(1), pp. 34-59.

Ratcliff, K., B. Riddle, and J.M. Yinger. 1990. “The Fiscal Condition of School Districts in Nebraska: Is Small Beautiful?” Economics of Education Review, 9:81-99.

Sell, Randall S., F. Larry Leistritz, and JoAnn M. Thompson, 1996. "Socio-economic Impacts of School Consolidation on Host and Vacated Communities," Agricultural Economics Reports, No. 347: Department of Agricultural Economics, North Dakota State University.

Steifel, Leanna, Amy Ellen Schwartz, Carole Portas, and Dae Yeop Kim. 2003. "School Budgeting and School Performance: The Impact of New York City's Performance Driven Budgeting Initiative,” Journal of Education Finance, 28, pp. 403-424. 
Figure 1. Annual School Closures in Illinois

By School Type, 1972-2005

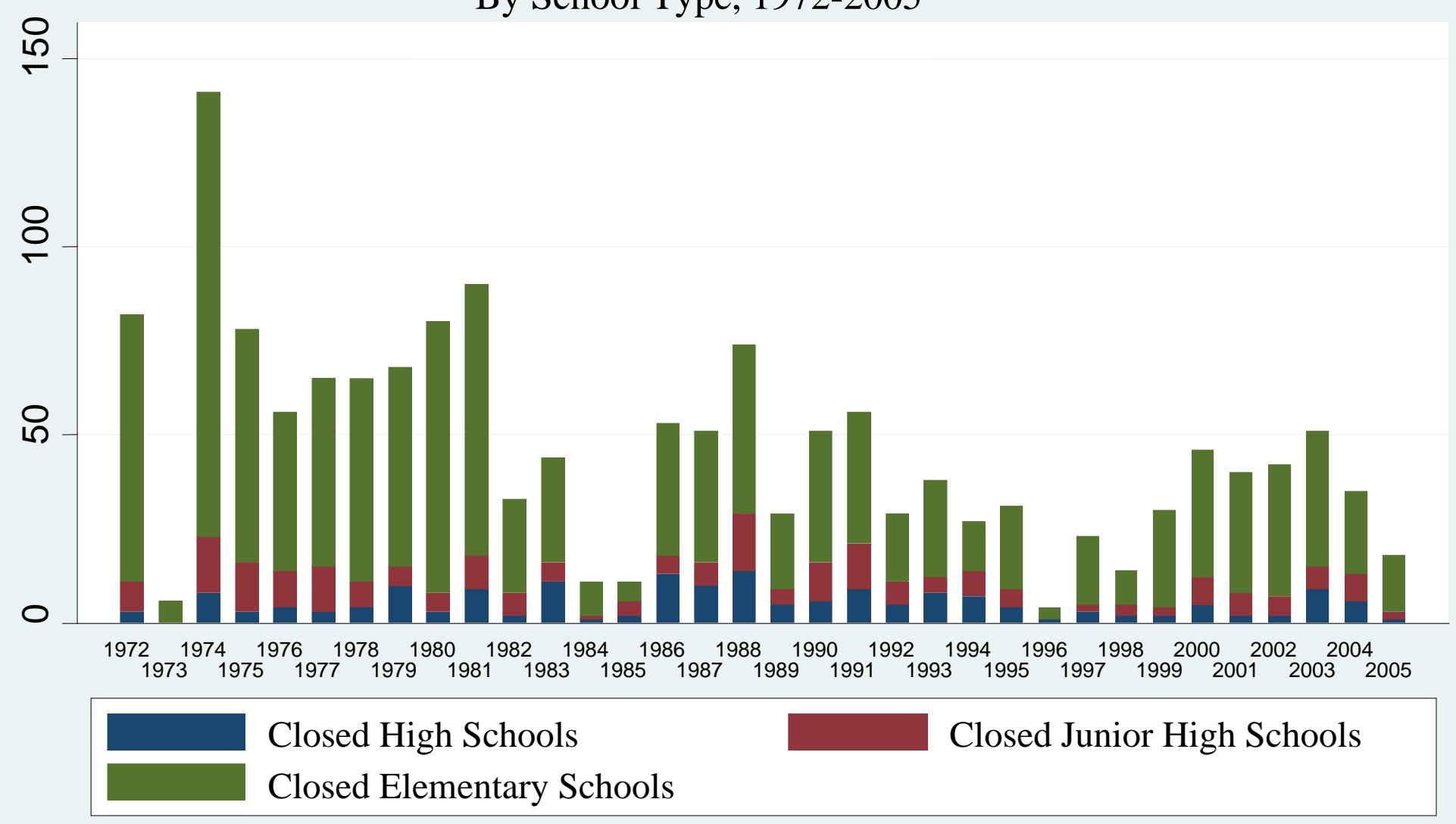

Data: Illinois State Board of Education and Regional Office of Education surveys 
Figure 2. Median Annual Amounts Leading to Elementary School Closure $\mathrm{T}=0$ is the last year the school was open
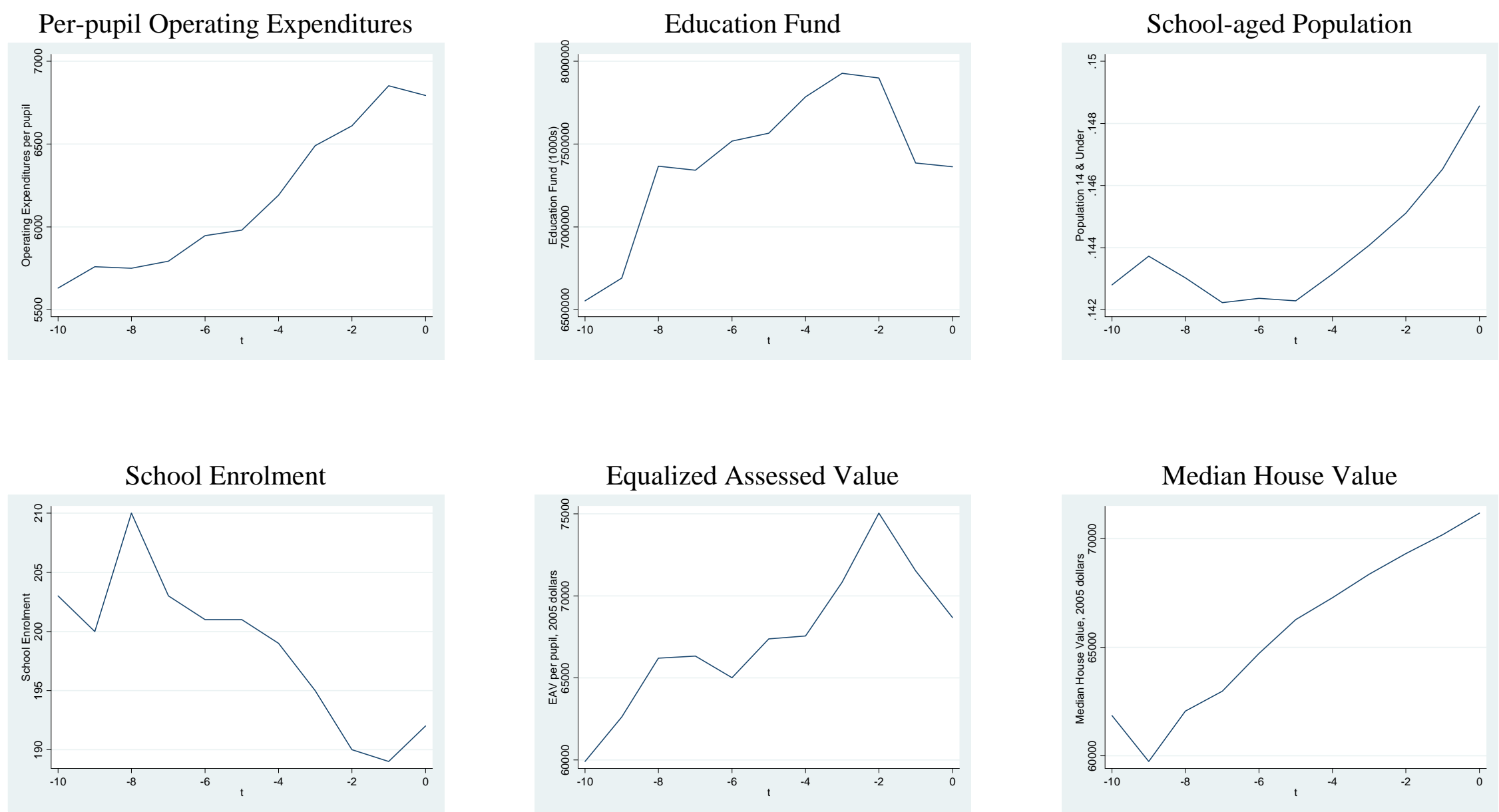
Figure 3. Median Annual Amounts Leading to Junior High School Closure $\mathrm{T}=0$ is the last year the school was open
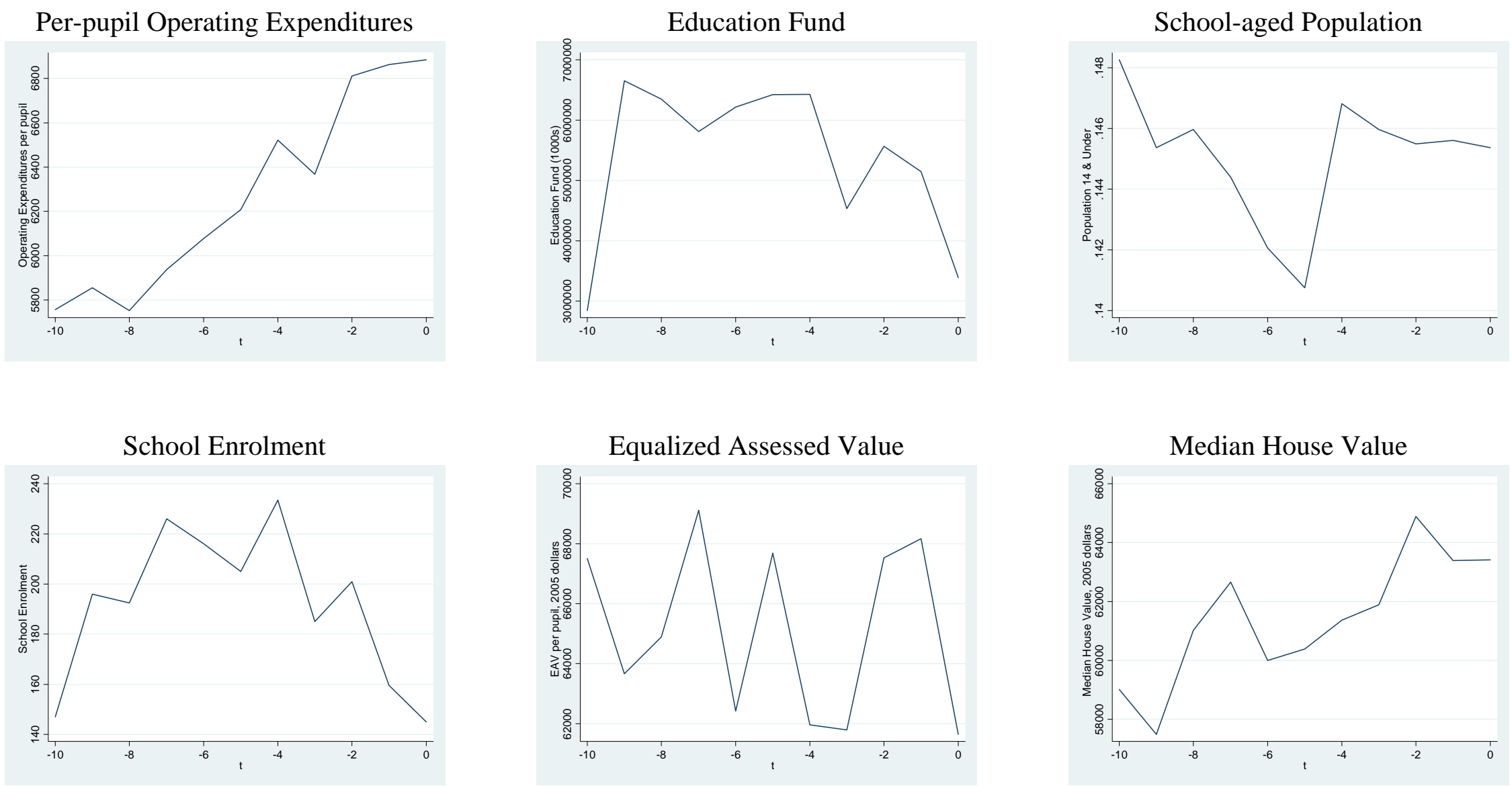
Table 1. Summary Statistics for Illinois Elementary Schools

\begin{tabular}{|c|c|c|c|c|c|}
\hline & \multicolumn{2}{|c|}{ School Closes } & \multicolumn{2}{|c|}{ Open Schools } & \multirow{2}{*}{$\begin{array}{l}\text { Difference in } \\
\text { Means Test }\end{array}$} \\
\hline & Mean & St. Error & Mean & St. Error & \\
\hline \multicolumn{6}{|l|}{ School Characteristics } \\
\hline Enrolment & 238.78 & 3.51 & 382.70 & 1.48 & 29.71 \\
\hline \% Black Students & 13.71 & 0.67 & 9.97 & 0.14 & 7.50 \\
\hline \% Latino Students & 2.61 & 0.20 & 7.08 & 0.11 & 12.35 \\
\hline \% Low Income Students & 40.18 & 0.65 & 30.14 & 0.18 & 16.26 \\
\hline Attendance Rate & 95.15 & 0.04 & 95.51 & 0.01 & 11.43 \\
\hline Math, Does Not Meet Goals & 14.36 & 0.41 & 12.51 & 0.10 & 5.25 \\
\hline Math, Exceeds Goals & 22.97 & 0.42 & 30.56 & 0.14 & 16.14 \\
\hline Reading, Does Not Meet Goals & 27.42 & 0.16 & 24.91 & 0.12 & 6.04 \\
\hline Reading, Exceeds Goals & 20.00 & 0.33 & 23.95 & 0.10 & 11.53 \\
\hline \multicolumn{6}{|l|}{ District Characteristics } \\
\hline$\overline{\text { EAV per Pupil }}$ & 79882.82 & 1938.88 & 118576.70 & 872.93 & 13.34 \\
\hline School Tax Rate & 4.27 & 0.05 & 3.94 & 0.01 & 7.74 \\
\hline Education Fund Rate & 77.38 & 0.22 & 73.90 & 0.08 & 13.77 \\
\hline Per-pupil Expenditures & 6531.80 & 33.47 & 7050.17 & 12.23 & 12.81 \\
\hline Teacher Salary & 43930.19 & 192.50 & 47945.09 & 67.59 & 18.80 \\
\hline Elementary District & 0.21 & 0.01 & 0.33 & 0.004 & 9.60 \\
\hline \multicolumn{6}{|l|}{ Town Characteristics } \\
\hline Povery Rate & 1.57 & 0.08 & 0.88 & 0.02 & 10.25 \\
\hline \% Population Rural & 38.47 & 1.19 & 25.46 & 0.36 & 11.46 \\
\hline Median House Value & 75826.49 & 148.64 & 122103.60 & 693.37 & 20.47 \\
\hline Vacancy Rate O-O Housing & 7.97 & 0.08 & 6.13 & 0.02 & 22.39 \\
\hline Median Household Income & 39304.80 & 329.05 & 51465.80 & 165.40 & 22.59 \\
\hline \multicolumn{6}{|l|}{ County Characteristics } \\
\hline Census Designated Metro & 0.440 & 0.010 & 0.660 & 0.004 & 17.70 \\
\hline \% Population 14 \& Under & 0.145 & 0.0004 & 0.155 & 0.0002 & 20.79 \\
\hline Unemployment Rate & 5.78 & 0.05 & 5.49 & 0.01 & 7.45 \\
\hline \% Pop HS Diploma & 34.82 & 0.14 & 31.87 & 0.05 & 16.96 \\
\hline$\%$ Pop BA/BS & 11.31 & 0.11 & 14.50 & 0.05 & 19.42 \\
\hline Tax Capped County & 0.11 & 0.01 & 0.18 & 0.003 & 6.77 \\
\hline Number of Schools & 221 & & 1477 & & \\
\hline
\end{tabular}

Data: ISBE, Census, BLS, IDES, 1991-2005. Illinois schools excluding Cook County, all dollars real 2005. Absolute t-statistics reported for difference in means tests, all significantly different at the $1 \%$ level. 
Table 2. Summary Statistics for Illinois Junior High Schools

\begin{tabular}{|c|c|c|c|c|c|}
\hline & \multicolumn{2}{|c|}{ School Closes } & \multicolumn{2}{|c|}{ Open Schools } & \multirow{2}{*}{$\begin{array}{l}\text { Difference in } \\
\text { Means Test }\end{array}$} \\
\hline & Mean & St. Error & Mean & St. Error & \\
\hline \multicolumn{6}{|l|}{$\underline{\text { School Characteristics }}$} \\
\hline Enrolment & 289.54 & 11.69 & 429.60 & 4.53 & $8.86^{* * *}$ \\
\hline \% Black Students & 20.67 & 1.67 & 7.42 & 0.23 & $14.33 * * *$ \\
\hline \% Latino Students & 1.84 & 0.23 & 4.96 & 0.17 & $5.45 * * *$ \\
\hline \% Low Income Students & 38.58 & 1.35 & 26.18 & 0.28 & $12.01 * * *$ \\
\hline Attendance Rate & 93.49 & 0.20 & 94.70 & 0.03 & $10.93 * * *$ \\
\hline Math, Does Not Meet Goals & 31.18 & 1.41 & 26.65 & 0.33 & $3.76 * * *$ \\
\hline Math, Exceeds Goals & 14.58 & 0.64 & 20.26 & 0.21 & $7.74 * * *$ \\
\hline Reading, Does Not Meet Goals & 31.49 & 0.93 & 25.34 & 0.19 & $8.65 * * *$ \\
\hline Reading, Exceeds Goals & 16.21 & 0.58 & 17.77 & 0.17 & $2.65 * * *$ \\
\hline \multicolumn{6}{|l|}{ District Characteristics } \\
\hline EAV per Pupil & 69372.24 & 2033.33 & 104501.80 & 1402.58 & $7.16^{* * *}$ \\
\hline School Tax Rate & 4.20 & 0.08 & 4.18 & 0.02 & 0.28 \\
\hline Education Fund Rate & 77.61 & 0.45 & 74.04 & 0.14 & $7.08 * * *$ \\
\hline Per-pupil Expenditures & 6595.93 & 67.67 & 6931.72 & 21.35 & $4.46 * * *$ \\
\hline Teacher Salary & 42632.84 & 342.80 & 46786.89 & 119.84 & $9.89 * * *$ \\
\hline Unit District & 0.86 & 0.02 & 0.86 & 0.010 & 0.15 \\
\hline \multicolumn{6}{|l|}{ Town Characteristics } \\
\hline Povery Rate & 4.20 & 0.44 & 0.88 & 0.02 & $21.58 * * *$ \\
\hline \% Population Rural & 45.75 & 2.45 & 31.95 & 0.68 & $5.69 * * *$ \\
\hline Median House Value & 71796.76 & 1980.66 & 111729.20 & 1182.55 & $9.82 * * *$ \\
\hline Vacancy Rate O-O Housing & 8.86 & 0.20 & 6.29 & 0.04 & $17.01 * * *$ \\
\hline $\begin{array}{l}\text { Median Household Income } \\
\text { County Characteristics }\end{array}$ & 38716.40 & 630.12 & 49089.42 & 286.50 & $10.45^{* * *}$ \\
\hline Census Designated Metro & 0.455 & 0.025 & 0.572 & 0.007 & $4.47 * * *$ \\
\hline \% Population 14 \& Under & 0.145 & 0.001 & 0.151 & 0.0003 & $6.90 * * *$ \\
\hline Unemployment Rate & 5.71 & 0.10 & 5.36 & 0.03 & $3.80 * * *$ \\
\hline \% Pop HS Diploma & 35.43 & 0.32 & 33.07 & 0.10 & $6.63 * * *$ \\
\hline \% Pop BA/BS & 11.12 & 0.25 & 13.72 & 0.09 & $8.18 * * *$ \\
\hline Tax Capped County & 0.03 & 0.01 & 0.15 & 0.010 & $4.84 * * *$ \\
\hline Number of Schools & 60 & & 455 & & \\
\hline
\end{tabular}

Data: ISBE, Census, BLS, IDES, 1991-2005. Illinois schools excluding Cook County, all dollars real 2005. Absolute t-statistics reported for difference in means tests. *** denotes significant at $1 \%$ level. 
Table 3. The Effect of School and District Characteristics on Elementary School Closures

\begin{tabular}{|c|c|c|c|c|}
\hline Variables & (1) & (2) & (3) & (4) \\
\hline Ln(Enrolment) & & $\begin{array}{l}-0.0992 * * * \\
(0.0135)\end{array}$ & $\begin{array}{l}-0.0904^{* * *} \\
(0.0129)\end{array}$ & $\begin{array}{l}-0.0901^{* * *} \\
(0.0129)\end{array}$ \\
\hline Real EAV per pupil, (mils) & $\begin{array}{l}-0.1003 \\
(0.1724)\end{array}$ & & $\begin{array}{l}0.1389 * * \\
(0.0561)\end{array}$ & $\begin{array}{l}0.1370^{* *} \\
(0.0559)\end{array}$ \\
\hline Per Pupil Expenditures (1000s) & $\begin{array}{l}0.0032 \\
(0.0062)\end{array}$ & & $\begin{array}{l}-0.0149 * * * \\
(0.0049)\end{array}$ & $\begin{array}{l}-0.0146^{* * *} \\
(0.0049)\end{array}$ \\
\hline School Tax Rate & $\begin{array}{l}0.0134 \\
(0.0101)\end{array}$ & & $\begin{array}{l}0.0051 \\
(0.0052)\end{array}$ & $\begin{array}{l}0.0048 \\
(0.0052)\end{array}$ \\
\hline Teacher Salary & $\begin{array}{l}-0.4262 * * * \\
(0.1028)\end{array}$ & & $\begin{array}{l}-0.0847 \\
(0.0960)\end{array}$ & $\begin{array}{l}-0.0549 \\
(0.0961)\end{array}$ \\
\hline Education Fund Rate & $\begin{array}{l}0.0024 * * * \\
(0.0008)\end{array}$ & & $\begin{array}{l}0.0003 \\
(0.0005)\end{array}$ & $\begin{array}{l}0.0003 \\
(0.0005)\end{array}$ \\
\hline Elementary District & $\begin{array}{l}-0.0339 * \\
(0.0181)\end{array}$ & $\begin{array}{l}-0.0300^{* *} \\
(0.0132)\end{array}$ & $\begin{array}{l}-0.0344^{* * *} \\
(0.0120)\end{array}$ & $\begin{array}{l}-0.0334 * * * \\
(0.0119)\end{array}$ \\
\hline \% Latino Students & & $\begin{array}{l}-0.0013 \\
(0.0008)\end{array}$ & $\begin{array}{l}-0.0007 \\
(0.0007)\end{array}$ & $\begin{array}{l}-0.0008 \\
(0.0007)\end{array}$ \\
\hline \% Black Students & & $\begin{array}{l}0.0001 \\
(0.0004)\end{array}$ & $\begin{array}{l}0.0005 \\
(0.0004)\end{array}$ & $\begin{array}{l}0.0004 \\
(0.0004)\end{array}$ \\
\hline \% Low Income Students & & $\begin{array}{l}0.0009 * * * \\
(0.0003)\end{array}$ & $\begin{array}{l}0.0008^{* *} \\
(0.0003)\end{array}$ & $\begin{array}{l}0.0007^{* *} \\
(0.0003)\end{array}$ \\
\hline Average Teacher Experience & & $\begin{array}{l}0.0030 \\
(0.0023)\end{array}$ & $\begin{array}{l}0.0039 * \\
(0.0023)\end{array}$ & $\begin{array}{l}0.0037^{*} \\
(0.0023)\end{array}$ \\
\hline Percent not Meeting Math Test Goals & & & & $\begin{array}{l}0.0003 \\
(0.0002)\end{array}$ \\
\hline Percent Exceeding Math Test Goals & & & & $\begin{array}{l}-0.0003 \\
(0.0002)\end{array}$ \\
\hline Percent not Meeting Reading Test Goals & & & & $\begin{array}{l}-0.0002 \\
(0.0002)\end{array}$ \\
\hline Percent Exceeding Reading Test Goals & & & & $\begin{array}{l}-0.0004^{*} \\
(0.0002)\end{array}$ \\
\hline
\end{tabular}

$\mathrm{N}=17356$. Robust standard errors in parentheses. ${ }^{* * *} \mathrm{p}<0.01,{ }^{* *} \mathrm{p}<0.05,{ }^{*} \mathrm{p}<0.1$

Data: Illinois State Board of Education, 1991-2005. Illinois elementary schools outside of Cook County 
Table 4. Community Characteristics and Elementary School Closures

\begin{tabular}{|c|c|c|}
\hline Variables & $(1)$ & $(2)$ \\
\hline \multirow[t]{2}{*}{ Population 14 \& Under } & $-1.1508 * *$ & -0.6922 \\
\hline & $(0.4773)$ & $(0.4267)$ \\
\hline \multirow[t]{2}{*}{ Poverty Rate } & 0.0000 & -0.0013 \\
\hline & $(0.0020)$ & $(0.0018)$ \\
\hline \multirow[t]{2}{*}{ Median HH Income (10000s) } & -0.0146 & -0.0167 \\
\hline & $(0.0161)$ & $(0.0117)$ \\
\hline \multirow[t]{2}{*}{ Unemployment Rate } & -0.0015 & -0.0006 \\
\hline & $(0.0032)$ & $(0.0030)$ \\
\hline \multirow[t]{2}{*}{ Median House Value (10000s) } & -0.0035 & -0.0003 \\
\hline & $(0.0054)$ & $(0.0045)$ \\
\hline \multirow[t]{2}{*}{ O-O Vacancy Rate } & & 0.0032 \\
\hline & & $(0.0023)$ \\
\hline \multirow[t]{2}{*}{ \% Employed in Agriculture } & & 0.0034 \\
\hline & & $(0.0033)$ \\
\hline \multirow[t]{2}{*}{ \% Immigrant } & & $-0.0055 * *$ \\
\hline & & $(0.0022)$ \\
\hline \multirow[t]{2}{*}{ Metro Metro > 1 million } & -0.0281 & -0.0114 \\
\hline & $(0.0432)$ & $(0.0392)$ \\
\hline \multirow[t]{2}{*}{ Metro 250k to 1 million } & $-0.0639 * * *$ & $-0.0541 * *$ \\
\hline & $(0.0210)$ & $(0.0210)$ \\
\hline \multirow[t]{2}{*}{ Metro < 250k } & -0.0361 & -0.0405 \\
\hline & $(0.0301)$ & $(0.0251)$ \\
\hline \multirow[t]{2}{*}{ Urban > 20k, Metro-Adjacent } & $-0.0420 *$ & $-0.0388 *$ \\
\hline & $(0.0246)$ & $(0.0233)$ \\
\hline \multirow[t]{2}{*}{ Urban $>20 \mathrm{k}$, not Metro-Adjacent } & -0.0303 & -0.0267 \\
\hline & $(0.0326)$ & $(0.0334)$ \\
\hline \multirow[t]{2}{*}{ Urban > 2500, Metro-Adjacent } & $-0.0465 *$ & $-0.0497 * *$ \\
\hline & $(0.0241)$ & $(0.0204)$ \\
\hline \multirow[t]{2}{*}{ Urban $>$ 2500, not Metro-Adjacent } & -0.0238 & -0.0229 \\
\hline & $(0.0310)$ & $(0.0283)$ \\
\hline \multirow[t]{2}{*}{ Population with HS Diploma } & & 0.0037 \\
\hline & & $(0.0022)$ \\
\hline \multirow[t]{2}{*}{ Population with BA/BS } & & 0.0007 \\
\hline & & $(0.0040)$ \\
\hline \multirow[t]{2}{*}{ Population with Grad Degree } & & 0.0053 \\
\hline & & $(0.0053)$ \\
\hline \multirow[t]{2}{*}{ County Has Property Tax Cap } & & -0.0073 \\
\hline & & $(0.0155)$ \\
\hline
\end{tabular}


Table 5. The Effect of School and District Characteristics on Junior High School Closures

Variables

Ln(Enrolment)

Real EAV per pupil, (mils)

Per Pupil Expenditures (1000s)

School Tax Rate

Teacher Salary

Education Fund Rate

Unit District Indicator

\% Latino Students

\% Black Students

\% Low Income Students

Average Teacher Experience

Percent not Meeting Math Test Goals

Percent Exceeding Math Test Goals

Percent not Meeting Reading Test Goals

Percent Exceeding Reading Test Goals
(1)

(2)

$-0.0178$

(0.0178)

$-0.0425^{* * *}-0.0265$

(0.0152) (0.0173)

$-0.1870$

(0.2180)

(0.2473)

$0.0167^{*}$

$(0.0092)$

$-0.0055$

(0.0106)

$-0.2386$

(0.2340)

0.0009

(0.0010)

-0.0790 *

(0.0466)

$-0.0104$

(0.0093)

$-0.0073 \quad-0.0068$

(0.0072) (0.0073)

$-0.2532 \quad-0.2243$

(0.1906) (0.1823)

$-0.0002 \quad-0.0003$

(0.0008) (0.0008)

$\begin{array}{lll}-0.0346 & -0.0270 \quad-0.0281\end{array}$

$\begin{array}{lll}(0.0313) & (0.0327) \quad(0.0327)\end{array}$

$\begin{array}{lll}-0.0030 & -0.0015 & -0.0016\end{array}$

$\begin{array}{lll}(0.0020) & (0.0014) \quad(0.0014)\end{array}$

$0.0017 * * \quad 0.0021 * * * \quad 0.0020 * * *$

$\begin{array}{lll}(0.0008) & (0.0007) \quad(0.0007)\end{array}$

$\begin{array}{lll}0.0006 & 0.0001 & 0.0001\end{array}$

$\begin{array}{lll}(0.0005) & (0.0006) \quad(0.0006)\end{array}$

$\begin{array}{lll}-0.0041 & -0.0009 & -0.0012\end{array}$

$(0.0046) \quad(0.0040) \quad(0.0040)$

0.0002

(0.0002)

$-0.0007$

(0.0006)

$-0.0003$

(0.0004)

0.0006

(0.0004)

$\mathrm{N}=4945$. Robust standard errors in parentheses. ${ }^{* * *} \mathrm{p}<0.01,{ }^{* *} \mathrm{p}<0.05,{ }^{*} \mathrm{p}<0.1$

Data: Illinois State Board of Education, 1991-2005. Illinois junior high schools outside of Cook County. 
Table 6. Community Characteristics and Junior High School Closures

\begin{tabular}{|c|c|c|}
\hline Variables & (1) & (2) \\
\hline Population 14 \& Under & $\begin{array}{l}-0.5103 \\
(0.6193)\end{array}$ & $\begin{array}{l}-0.0005 \\
(0.6302)\end{array}$ \\
\hline Poverty Rate & $\begin{array}{l}0.0105^{* * *} \\
(0.0035)\end{array}$ & $\begin{array}{l}0.0085^{* * *} \\
(0.0031)\end{array}$ \\
\hline Median HH Income (10000s) & $\begin{array}{l}-0.0070 \\
(0.0177)\end{array}$ & $\begin{array}{l}-0.0009 \\
(0.0167)\end{array}$ \\
\hline Unemployment Rate & $\begin{array}{l}-0.0049 \\
(0.0051)\end{array}$ & $\begin{array}{l}-0.0010 \\
(0.0039)\end{array}$ \\
\hline Median House Value (10000s) & $\begin{array}{l}-0.0068 \\
(0.0045)\end{array}$ & $\begin{array}{l}-0.0035 \\
(0.0049)\end{array}$ \\
\hline O-O Vacancy Rate & & $\begin{array}{l}0.0085 * * \\
(0.0035)\end{array}$ \\
\hline \% Employed in Agriculture & & $\begin{array}{l}0.0018 \\
(0.0043)\end{array}$ \\
\hline \% Immigrant & & $\begin{array}{l}-0.0043^{* *} \\
(0.0019)\end{array}$ \\
\hline Metro Metro > 1 million & $\begin{array}{l}0.0964 \\
(0.0776)\end{array}$ & $\begin{array}{l}0.0724 \\
(0.0667)\end{array}$ \\
\hline Metro $250 \mathrm{k}$ to 1 million & $\begin{array}{l}0.0640 \\
(0.0851)\end{array}$ & $\begin{array}{l}0.0583 \\
(0.0778)\end{array}$ \\
\hline Metro $<250 \mathrm{k}$ & $\begin{array}{l}0.0423 \\
(0.0835)\end{array}$ & $\begin{array}{l}-0.0066 \\
(0.0631)\end{array}$ \\
\hline Urban > 20k, Metro-Adjacent & $\begin{array}{l}-0.0335 \\
(0.0311)\end{array}$ & $\begin{array}{l}-0.0340 \\
(0.0245)\end{array}$ \\
\hline Urban $>$ 20k, not Metro-Adjacent & $\begin{array}{l}-0.0201 \\
(0.0463)\end{array}$ & $\begin{array}{l}-0.0386 \\
(0.0253)\end{array}$ \\
\hline Urban > 2500, Metro-Adjacent & $\begin{array}{l}0.0031 \\
(0.0501)\end{array}$ & $\begin{array}{l}-0.0095 \\
(0.0390)\end{array}$ \\
\hline Urban > 2500, not Metro-Adjacent & $\begin{array}{l}0.0791 \\
(0.0854)\end{array}$ & $\begin{array}{l}0.0653 \\
(0.0710)\end{array}$ \\
\hline Population with HS Diploma & & $\begin{array}{l}0.0046 \\
(0.0032)\end{array}$ \\
\hline Population with BA/BS & & $\begin{array}{l}-0.0002 \\
(0.0042)\end{array}$ \\
\hline Population with Grad Degree & & $\begin{array}{l}0.0122^{* *} \\
(0.0051)\end{array}$ \\
\hline County Has Property Tax Cap & & $\begin{array}{l}-0.0317^{*} \\
(0.0180)\end{array}$ \\
\hline
\end{tabular}


Table 7. The Determinants of Elementary and Junior High School Closures

\begin{tabular}{|c|c|c|c|c|c|}
\hline Variables & Elementary & Jr High & Variables & Elementary & Jr High \\
\hline \multirow[t]{2}{*}{ Ln(Enrolment) } & $-0.0917 * * *$ & -0.0107 & Population 14 \& Under & -0.2972 & -0.4536 \\
\hline & $(0.0124)$ & $(0.0131)$ & & $(0.3460)$ & $(0.5371)$ \\
\hline \multirow[t]{2}{*}{ Real EAV per pupil, (mils) } & $0.1348^{* *}$ & -0.1180 & Poverty Rate & $-0.0049 * * *$ & $0.0066^{* *}$ \\
\hline & $(0.0616)$ & $(0.2040)$ & & $(0.0016)$ & $(0.0026)$ \\
\hline \multirow[t]{2}{*}{ Per Pupil Expenditures (1000s) } & $-0.0120 * * *$ & $-0.0155^{*}$ & Median HH Income (10000s) & -0.0055 & 0.0052 \\
\hline & $(0.0046)$ & $(0.0079)$ & & $(0.0088)$ & $(0.0127)$ \\
\hline \multirow[t]{2}{*}{ School Tax Rate } & 0.0051 & -0.0029 & Median House Value (10000s) & -0.0001 & -0.0006 \\
\hline & $(0.0047)$ & $(0.0056)$ & & $(0.0023)$ & $(0.0033)$ \\
\hline \multirow[t]{2}{*}{ Education Fund Rate } & 0.0002 & -0.0004 & O-O Vacancy Rate & 0.0017 & $0.0046 *$ \\
\hline & $(0.0004)$ & $(0.0006)$ & & $(0.0018)$ & $(0.0025)$ \\
\hline \multirow[t]{2}{*}{ Teacher Salary } & -0.0486 & -0.0021 & \% Immigrant & $-0.0033 *$ & $-0.0041 * *$ \\
\hline & $(0.1076)$ & $(0.1604)$ & & $(0.0017)$ & $(0.0020)$ \\
\hline \multirow[t]{2}{*}{ \% Black Students } & 0.0001 & $0.0020 * * *$ & Metro Metro $>1$ million & -0.0412 & 0.0219 \\
\hline & $(0.0004)$ & $(0.0006)$ & & $(0.0310)$ & $(0.0413)$ \\
\hline \multirow[t]{2}{*}{ \% Low Income Students } & 0.0005 & -0.0003 & Metro $250 \mathrm{k}$ to 1 million & $-0.0555 * * *$ & 0.0085 \\
\hline & $(0.0003)$ & $(0.0005)$ & & $(0.0129)$ & $(0.0378)$ \\
\hline \multirow[t]{2}{*}{ Average Teacher Experience } & $0.0041 *$ & -0.0030 & Metro $<250 \mathrm{k}$ & $-0.0492 * * *$ & -0.0162 \\
\hline & $(0.0021)$ & $(0.0028)$ & & $(0.0130)$ & $(0.0306)$ \\
\hline \multirow[t]{2}{*}{ Percent not Meeting Math Test Goals } & $0.0004 *$ & 0.0003 & Urban $>$ 20k, Metro-Adjacent & $-0.0460 * * *$ & -0.0246 \\
\hline & $(0.0002)$ & $(0.0002)$ & & $(0.0111)$ & $(0.0163)$ \\
\hline \multirow[t]{2}{*}{ Percent Exceeding Math Test Goals } & -0.0003 & -0.0005 & Urban $>20 \mathrm{k}$, not Metro-Adjacent & $-0.0345^{* *}$ & -0.0240 \\
\hline & $(0.0002)$ & $(0.0005)$ & & $(0.0164)$ & $(0.0199)$ \\
\hline \multirow[t]{2}{*}{ Percent not Meeting Reading Test Goals } & -0.0001 & -0.0000 & Urban $>$ 2500, Metro-Adjacent & $-0.0515^{* * *}$ & -0.0145 \\
\hline & $(0.0002)$ & $(0.0003)$ & & $(0.0113)$ & $(0.0224)$ \\
\hline \multirow[t]{2}{*}{ Percent Exceeding Reading Test Goals } & $-0.0004 *$ & 0.0002 & Urban $>2500$, not Metro-Adjacent & $-0.0388 * * *$ & 0.0514 \\
\hline & $(0.0002)$ & $(0.0004)$ & & $(0.0142)$ & $(0.0566)$ \\
\hline \multirow[t]{2}{*}{ Elementary or Unit District Indicator } & $-0.0303 * * *$ & -0.0299 & County Has Property Tax Cap & 0.0018 & -0.0037 \\
\hline & $(0.0117)$ & $(0.0295)$ & & $(0.0138)$ & $(0.0215)$ \\
\hline
\end{tabular}

17356 elementary school observations, 4945 junior high observations. Robust standard errors in parentheses. ${ }^{* * *} \mathrm{p}<0.01,{ }^{* *} \mathrm{p}<0.05,{ }^{*} \mathrm{p}<0.1$

Data: ISBE, Census, BLS, IDES, 1991-2005. Illinois elementary and junior high schools outside of Cook County.

Additional variables: \% Latino students, unemployment rate, \% employed in agriculture, community education level. 
Table 8. The Role of Trends in Explaining Elementary School Closures with Select Subgroups

\begin{tabular}{|c|c|c|c|c|c|c|c|}
\hline \multirow[b]{3}{*}{ Variables } & \multicolumn{4}{|c|}{3 Year Trends } & \multicolumn{3}{|c|}{7 Year Trends } \\
\hline & & Rural & Top Quartile & Bottom Quartile & & Rural & Bottom Quartile \\
\hline & All & Counties & Expenditures & Enrolment & All & Counties & Enrolment \\
\hline \multirow[t]{2}{*}{ Ln(Enrolment) } & $-0.0036^{* * *}$ & -0.0010 & $-0.0033^{* * *}$ & -0.0042 & -0.0037 & $-8.33 e-05$ & -0.0012 \\
\hline & $(0.0008)$ & $(0.0006)$ & $(0.0009)$ & $(0.0031)$ & $(0.0028)$ & $(0.0003)$ & $(0.0013)$ \\
\hline \multirow[t]{2}{*}{ Real EAV per pupil, (mils) } & -0.0028 & -0.0064 & 0.0034 & -0.0110 & 0.0133 & -0.0001 & 0.0037 \\
\hline & $(0.0058)$ & $(0.0061)$ & $(0.0045)$ & $(0.0142)$ & $(0.0180)$ & $(0.0005)$ & $(0.0061)$ \\
\hline \multirow[t]{2}{*}{ Per Pupil Expenditures (1000s) } & -0.0003 & -0.0001 & -0.0006 & 0.0004 & -0.0008 & $-2.82 e-05$ & -0.00024 \\
\hline & $(0.0004)$ & $(0.0002)$ & $(0.0004)$ & $(0.0006)$ & $(0.0010)$ & $(9.69 \mathrm{e}-05)$ & $(0.0004)$ \\
\hline \multirow[t]{2}{*}{ Education Fund Rate } & 3.37e-05 & $8.46 \mathrm{e}-05 *$ & $-3.44 \mathrm{e}-05$ & $1.25 \mathrm{e}-05$ & $-6.75 e-05$ & $-2.44 \mathrm{e}-06$ & $-2.18 e-05$ \\
\hline & (5.87e-05) & $(4.64 \mathrm{e}-05)$ & $(4.51 \mathrm{e}-05)$ & $(0.0001)$ & (7.35e-05) & $(8.47 e-06)$ & $(2.96 \mathrm{e}-05)$ \\
\hline \multirow[t]{2}{*}{ Population 14 \& Under } & 0.0276 & 0.0334 & 0.0006 & 0.0151 & 0.0643 & 0.0002 & 0.0182 \\
\hline & $(0.0267)$ & $(0.0236)$ & $(0.0253)$ & $(0.0435)$ & $(0.0795)$ & $(0.0014)$ & $(0.0259)$ \\
\hline \multirow[t]{2}{*}{$\%$ not Meeting Math Test Goals } & $6.64 \mathrm{e}-05^{* *}$ & 8.47e-06 & $5.56 \mathrm{e}-05$ & 7.84e-05 & $6.45 e-05$ & $1.12 \mathrm{e}-06$ & $2.22 \mathrm{e}-05$ \\
\hline & $(3.01 \mathrm{e}-05)$ & $(1.31 \mathrm{e}-05)$ & $(3.65 e-05)$ & $(6.34 \mathrm{e}-05)$ & $(6.34 \mathrm{e}-05)$ & $(4.12 \mathrm{e}-06)$ & $(2.78 \mathrm{e}-05)$ \\
\hline \multirow[t]{2}{*}{ \% Exceeding Math Test Goals } & $-4.52 \mathrm{e}-06$ & $-1.30 \mathrm{e}-05$ & $-2.70 \mathrm{e}-08$ & $1.04 \mathrm{e}-05$ & 8.39e-05 & $1.06 \mathrm{e}-06$ & $2.65 e-05$ \\
\hline & $(2.47 \mathrm{e}-05)$ & $(9.24 \mathrm{e}-06)$ & $(2.76 e-05)$ & $(3.27 \mathrm{e}-05)$ & $(7.15 e-05)$ & $(3.63 e-06)$ & $(3.07 e-05)$ \\
\hline \multirow[t]{2}{*}{ \% not Meeting Reading Test Goals } & $-6.16 \mathrm{e}-05^{* *}$ & $-1.23 e-05$ & $-5.27 e-05$ & $-4.85 e-05$ & $-2.16 e-05$ & $-7.56 e-07$ & $-1.16 e-05$ \\
\hline & $(3.08 \mathrm{e}-05)$ & $(1.37 \mathrm{e}-05)$ & (3.39e-05) & $(4.69 \mathrm{e}-05)$ & $(4.86 e-05)$ & $(2.57 e-06)$ & $(1.62 \mathrm{e}-05)$ \\
\hline \multirow[t]{2}{*}{ \% Exceeding Reading Test Goals } & $-8.28 \mathrm{e}-05^{* *}$ & $-4.95 e-06$ & $-6.25 \mathrm{e}-05^{*}$ & -0.0001 & -0.0002 & $-1.26 \mathrm{e}-06$ & $-5.02 \mathrm{e}-05$ \\
\hline & (3.39e-05) & $(1.35 \mathrm{e}-05)$ & (3.67e-05) & $(9.27 \mathrm{e}-05)$ & $(0.0001)$ & $(4.16 \mathrm{e}-06)$ & $(5.36 \mathrm{e}-05)$ \\
\hline \multirow[t]{2}{*}{ Enrolment Trend } & 7.85e-06* & $3.26 \mathrm{e}-06$ & $6.83 e-06^{*}$ & $2.39 e-05$ & $2.78 \mathrm{e}-05$ & $9.58 \mathrm{e}-07$ & $1.03 e-05$ \\
\hline & $(4.32 \mathrm{e}-06)$ & (3.53e-06) & $(4.14 \mathrm{e}-06)$ & $(2.13 e-05)$ & $(2.77 e-05)$ & $(3.32 \mathrm{e}-06)$ & $(1.31 \mathrm{e}-05)$ \\
\hline \multirow[t]{2}{*}{ EAV Trend } & $-1.54 \mathrm{e}-08$ & $-1.04 \mathrm{e}-08$ & $-9.63 e-09$ & $-9.07 e-09$ & $-6.19 e-08$ & $-1.53 e-09$ & $-1.76 \mathrm{e}-08$ \\
\hline & $(9.45 \mathrm{e}-09)$ & $(7.86 e-09)$ & $(6.46 e-09)$ & $(1.59 \mathrm{e}-08)$ & $(5.55 e-08)$ & $(4.92 \mathrm{e}-09)$ & $(1.90 \mathrm{e}-08)$ \\
\hline \multirow[t]{2}{*}{ Expenditures Trend } & $8.31 \mathrm{e}-07^{*}$ & $2.70 \mathrm{e}-07$ & $4.55 e-07$ & $1.19 \mathrm{e}-06$ & $3.05 e-06$ & $6.50 \mathrm{e}-08$ & $1.03 e-06$ \\
\hline & (4.99e-07) & $(2.18 \mathrm{e}-07)$ & (3.95e-07) & $(1.36 \mathrm{e}-06)$ & $(2.56 e-06)$ & $(2.24 \mathrm{e}-07)$ & $(1.17 \mathrm{e}-06)$ \\
\hline \multirow[t]{2}{*}{ Education Fund Rate Trend } & $-0.0001^{* *}$ & $-0.0001 *$ & $-3.36 e-05$ & -0.0001 & $-1.22 \mathrm{e}-05$ & $1.57 \mathrm{e}-06$ & $-1.74 \mathrm{e}-06$ \\
\hline & (5.35e-05) & $(5.49 \mathrm{e}-05)$ & (3.58e-05) & $(0.0001)$ & $(4.55 \mathrm{e}-05)$ & $(5.73 e-06)$ & $(1.46 \mathrm{e}-05)$ \\
\hline \multirow[t]{2}{*}{ School Age Population Trend } & $0.0426^{*}$ & $0.0443^{*}$ & $0.0334 *$ & 0.0226 & -0.0416 & 0.0001 & -0.0316 \\
\hline & $(0.0226)$ & $(0.0247)$ & $(0.0191)$ & $(0.0352)$ & $(0.0953)$ & $(0.0014)$ & $(0.0433)$ \\
\hline Observations & 13700 & 2975 & 6884 & 1318 & 604 & 425 & 808 \\
\hline
\end{tabular}

Additional variables as Table 7. Robust SEs in parentheses. ${ }^{* * *} \mathrm{p}<0.01,{ }^{* *} \mathrm{p}<0.05,{ }^{*} \mathrm{p}<0.1$. Data: ISBE, Census, BLS, IDES, 1991-2005. 
Table 9. The Role of Trends in Explaining Junior High School Closures

\begin{tabular}{llll} 
Variables & 3 Year Trends & 5 Year Trends & 7 Year Trends \\
\hline Ln(Enrolment) & -0.0005 & -0.0009 & -0.0012 \\
Real EAV per pupil, (mils) & $(0.0009)$ & $(0.0014)$ & $(0.0017)$ \\
& $-0.0868 * * *$ & $-0.0883^{* * *}$ & $-0.0852^{* * *}$ \\
Per Pupil Expenditures (1000s) & $(0.0206)$ & $(0.0303)$ & $(0.0323)$ \\
Education Fund Rate & 0.0009 & $0.0018 *$ & 0.0019 \\
& $(0.0007)$ & $(0.0010)$ & $(0.0012)$ \\
Population 14 \& Under & $-6.26 \mathrm{e}-05$ & -0.0001 & $-4.57 \mathrm{e}-05$ \\
& $(8.57 \mathrm{e}-05)$ & $(0.0001)$ & $(0.0002)$ \\
Enrolment Trend & -0.0020 & -0.1060 & -0.1490 \\
& $(0.0378)$ & $(0.0835)$ & $(0.1010)$ \\
EAV Trend & $-5.94 \mathrm{e}-06$ & $3.90 \mathrm{e}-06$ & $-4.42 \mathrm{e}-07$ \\
& $(4.77 \mathrm{e}-06)$ & $(7.33 \mathrm{e}-06)$ & $(1.03 \mathrm{e}-05)$ \\
Per-Pupil Expenditures Trend & $2.12 \mathrm{e}-07 * * *$ & $3.56 \mathrm{e}-08$ & $1.15 \mathrm{e}-07$ \\
& $(6.75 \mathrm{e}-08)$ & $(7.66 \mathrm{e}-08)$ & $(8.47 \mathrm{e}-08)$ \\
Education Fund Rate Trend & $1.65 \mathrm{e}-07$ & $-2.03 \mathrm{e}-07$ & $-1.15 \mathrm{e}-06$ \\
& $(1.53 \mathrm{e}-06)$ & $(1.43 \mathrm{e}-06)$ & $(1.53 \mathrm{e}-06)$ \\
School Age Population Trend & $3.03 \mathrm{e}-05$ & $-1.31 \mathrm{e}-05$ & -0.0002 \\
& $(8.38 \mathrm{e}-05)$ & $(0.0002)$ & $(0.0002)$ \\
Observations & 0.0027 & 0.1940 & $0.3370 *$ \\
Includes unit district indicator. Robust standard & $(0.0414)$ & $(0.1410)$ & $(0.1920)$ \\
\end{tabular}

Data: ISBE, Census, BLS, IDES, 1991-2005. Illinois elementary schools outside of Cook County 